\title{
Prediksi Perilaku Lentur Kolom Beton Bertulang Mutu Tinggi Terhadap Kombinasi Beban Perpindahan Monotonik dan Aksial Rendah
}

\author{
Muhammad Ali Rofiq ${ }^{1, *}$, Harun Alrasyid ${ }^{1}$, Data Iranata ${ }^{1}$, Djoko Irawan ${ }^{1}$ \\ Departemen Teknik Sipil, Institut Teknologi Sepuluh Nopember, Surabaya ${ }^{1}$ \\ Koresponden*, Email:rofiq.raharja@gmail.com
}

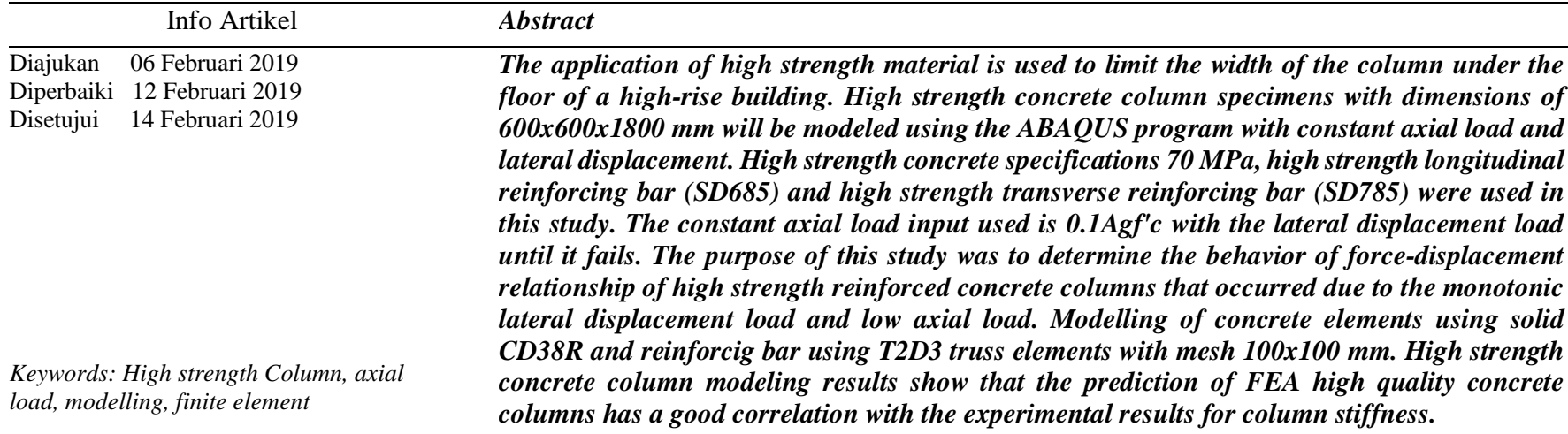

\begin{abstract}
Abstrak
Penerapan material mutu tinggi mulai digunakan untuk membatasi luas kolom dilantai bawah struktur gedung tinggi. Spesimen kolom beton mutu tinggi dengan dimensi 600x600x1800 mm akan dimodelkan menggunakan program bantu ABAQUS dengan beban aksial secara konstan dan lateral displacement. Spesifikasi beton mutu tinggi $70 \mathrm{MPa}$, tulangan longitudinal mutu tinggi (SD685) dan tulangan transversal mutu tinggi (SD785) digunakan pada penelitian ini. Input beban aksial konstan yang digunakan adalah $0,1 A_{g} f^{\prime}{ }_{c}$ dengan beban lateral displacement sampai gagal. Tujuan penelitian ini adalah untuk mengetahui perilaku hubungan force terhadap displacement kolom beton bertulang mutu tinggi yang terjadi akibat beban perpindahanlateral monotonik dan beban aksial rendah. Pemodelan elemen beton menggunakan solid CD38R dan tulangan menggunakan elemen truss T2D3 dengan mesh 100x100 mm. Hasil pemodelan kolom beton mutu tinggi menunjukkan bahwa prediksi FEA kolom beton mutu tinggi mempunyai korelasi yang baik dengan hasil eksperimen untuk kekakuan kolom.
\end{abstract}

Kata kunci: Kolom mutu tinggi, beban aksial, pemodelan, elemen hingga

$\mathrm{MPa}$ ) yang masing-masing untuk tulangan longitudinal dan transversal. Mutu beton nominal yang digunakan adalah 70 MPa. Tulangan longitudinal SD 685 dan tulangan transversal SD785 dikembangkan di Jepang[1] dan dimodifikasi sedikit oleh Taiwan Concrete Institute[2]. Kajian eksperimental menggunakan material tersebut pada kolom beton bertulang diantaranya Ou dan Kurniawan[3];Ou dan Kurniawan[4]; Hwang et al.[5]; Ou et al.[6]; Liao et al.[7]. Penelitan ekperimental tersebut meliputi kajian lentur hingga geser pada kolom beton bertulang mutu tinggi.

Penelitian mengenai kolom bertulang mutu tinggi dengan menggunakan mutu-mutu tulangan tersebut masih dalam sebatas kajian eksperimental. Permodelan finite element pada kolom beton bertulang juga masih sebatas penggunaan mutu normal. Penelitian ini direncanakan adalah memodelkan hasil eksperimental yang dilakukan oleh Ou et al.[6]. Kolom hasil eksperimental yang dipilih adalah kolom yang mendapat beban siklik dengan beban aksial rendah. Adapun pembebanan yang dimodelkan dalam penelitian tersebut adalah 
kombinasi beban monotonic displacement dan aksial tekan rendah.

\section{Tinjauan Pustaka}

Besi beton mutu tinggi untuk tulagan longitudinal (SD 685) dan tulangan transversal (SD 785) dikembangkan di Jepang antara tahun 1985-1995. Material ini disyaratkan penggunaannya untuk bangunan tinggi di Jepang [1]. Setelah itu pada tahun 2010 besi beton SD 685 dan SD 785 dikembangkan di Taiwan [2]. Parameter kuat tarik besi beton SD 685 dan SD 785 disajikan pada Tabel 1. Kurva tegangan-regangan SD 685 dan SD 785 disajikan pada Gambar 1 dan Gambar 2.

Tabel 1. Parameter kuat tarik besi beton SD685, SD785

\begin{tabular}{lcc}
\hline Grade & SD685 & SD785 \\
\hline Yield strength , $\mathrm{MPa}$ & $685-785$ & $\geq 785$ \\
Tensile strength, min $\mathrm{MPa}$ & 860 & 930 \\
Strain at yield plateau, min \% & 1.4 & - \\
Total elongation, min \% & 10 & 8 \\
Ratio Tensile to Yield strength min & 1.25 & - \\
\hline
\end{tabular}

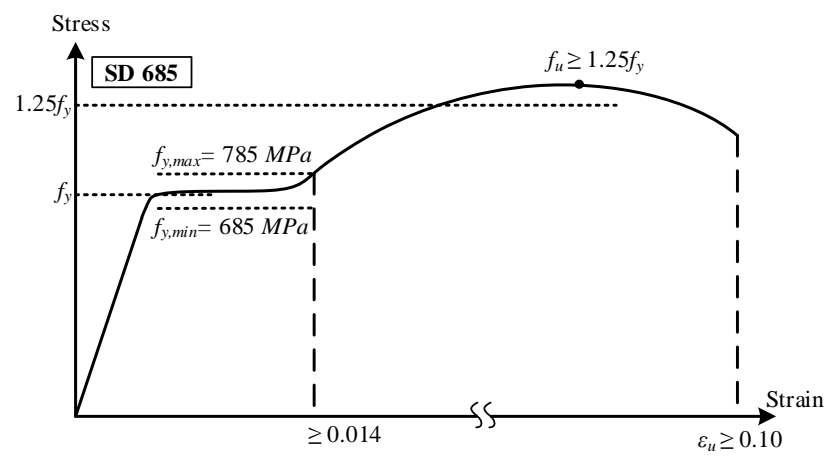

Gambar 1. Kurva Tegangan- Regangan SD685

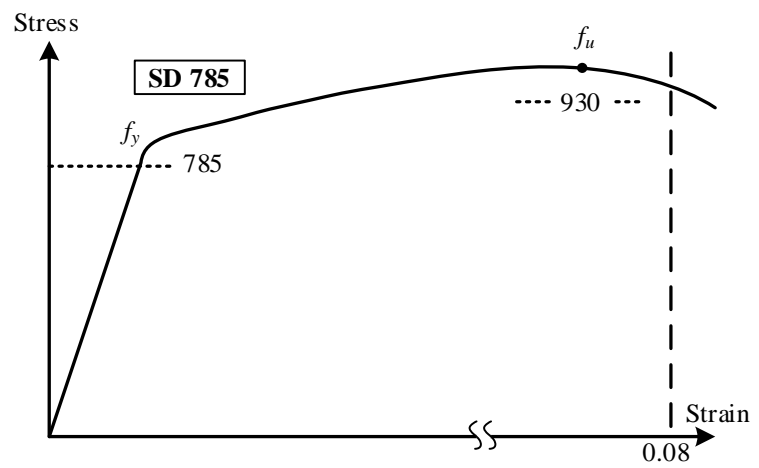

Gambar 2. Kurva Tegangan- Regangan SD785

Hwang et al.[5] melakukan penelitian dengan menggunakan mutu beton $f^{\prime}{ }_{c}$ 83-112 MPa dengan mutu besi tulangan SD685 dan SD785. Pada penelitian ini lima kolom dengan beban aksial 0,42 -0,67 $P / A_{g} f_{c}$ diuji. Persamaan confinement untuk kolom mutu tinggi diusulkan pada penelitian ini. Hasil penelitian menunjukkan bahwa persamaan yang diusulkan dapat digunakan untuk kekangan pada tulangan yang dapat mencapai kapasitas drift $\geq 3 \%$. PenelItian menggunakan material mutu tinggi juga dilakukan oleh Ou dan Kurniawan [3] dengan mutu beton 93-139 MPa dan dengan mutu tulangan SD 685 dan SD 785. Penelitian ini menggunakan lima kolom spesimen dengan meninjau perilaku geser kolom. Hasil dari penelitian menunjukkan bahwa SD785 tidak mengalami kelelehan pada beban puncak. Ou et al.[6] melakukan eksperimen pada empat kolom beton pracetak mutu tinggi dan dua kolom beton mutu tinggi untuk mengamati perilaku siklik kolom akibat beban perpindahan monotonik dan aksial rendah. Penelitian ini menggunakan mutu beton $f_{c}^{\prime} 70 \mathrm{MPa}$ dengan mutu besi tulangan SD685 dan SD785. Hasil penelitian menunjukkan kolom monolit dan kolom pracetak dengan tulangan tranversal hooked dapat mencapai kapasitas drift $\geq 3 \%$.

\section{Metode}

Metode penelitian dimulai dengan persiapan data dari eksperimen sebelumnya mengenai kolom beton mutu tinggi. Data properti dan geometri dari kolom beton beton mutu tinggi yang diambil dalam penelitian ini adalah data penelitian eksperimental yang dilakukan Ou et al.[6] mengenai perilaku siklik pada kolom pracetak mutu tinggi. Pemodelan kolom sesuai dengan data geometri. Pendefinisian perilaku material beton dan tulangan didapatkan dari data properti yang didekati dengan persamaan empiris. Persamaan empiris tersebut meliputi persamaan tegangan-regangan tekan beton, tarik beton, dan tarik tulangan. Dari hubungan tegangan-regangan kemudian dihitung menjadi hubungan regangan inelastistegangan leleh dan hubungan regangan inelastis-damage parameter untuk perilaku beton. Input hasil studi parameter beton dan tulangan menjadi acuan dalam input pemodelan kolom beton mutu tinggi. Kemudian hasil running pemodelan kolom berupa kurva force-displacement akan diverifikasikan dengan kurva hasil eksperimen dari Ou et al.[6].

\section{Material Properties}

Properti material yang diambil dari hasil uji tekan aktual beton, uji tarik aktual tulangan longitudinal SD685, dan tulangan transversal SD785. Adapun input material properties disajikan pada Tabel 2.

Parameter-parameter yang diinput ke definisi perilaku material khusunya material beton pada ABAQUS dapat disajikan pada Tabel 3. Parameter-parameter tersebut diinputkan ke dalam perilaku CDP pada beton. Parameter eksetrisitas, $\mathrm{FB}_{0} / \mathrm{FC}_{0}$, dan $\mathrm{K}$ sesuai yang direkomendasikan oleh ABAQUS. Parameter sudut dilatasi dan viskositas diasumsikan agar prediksi sesuai dengan hasil eksperimental. Parameter viskositas 0,001 diasumsikan tidak berbeda jauh terhadap 
hasil jika viskositas nol. Parameter yang mendefinisikan perilaku tarik tulangan disajikan pada Tabel 4. Perilaku tarik tulangan antara lain density, elastic, dan plastic yang diinputkan pada ABAQUS. Perilaku elastis pada tulangan didefinisikan oleh nilai Modulus Young dan poison ratio.

Tabel 2. Material Properties

\begin{tabular}{cc}
\hline Property & Value \\
\hline Beton & $f_{c}^{\prime}=74 \mathrm{MPa}$ \\
Tulangan longitudinal & $f_{y}=713 \mathrm{MPa}$ \\
SD685 & $f_{u}=932 \mathrm{MPa}$ \\
Tulangan transversal SD785 & $f_{y}=886 \mathrm{MPa}$ \\
& $f_{u}=1095 \mathrm{MPa}$ \\
\hline
\end{tabular}

Tabel 3. Parameter Beton

\begin{tabular}{lc}
\hline \multicolumn{1}{c}{ Property } & Value \\
\hline Density $\left(\mathrm{kg} / \mathrm{m}^{3}\right)$ & 2400 \\
Modulus Young $(\mathrm{MPa})$ & 35459 \\
Poison's Ratio & 0.2 \\
Dilation Angle & 40 \\
Eccentricity & 0.1 \\
FBo/FC 0 & 1.16 \\
K & 0.667 \\
Viscosity Parameter & 0,001 \\
Yield Strength & \\
(Compressive) & 74 \\
Yield Strength (Tensile) & 5.15 \\
\hline
\end{tabular}

Tabel 4. Parameter Tulangan

\begin{tabular}{lc}
\hline \multicolumn{1}{c}{ Property } & Value \\
\hline Density (ton $/ \mathrm{mm}^{3}$ ) & 0.0000000078 \\
Modulus Young $(\mathrm{MPa})$ & 200000 \\
Poison's Ratio & 0.3 \\
Yield Strength $(\mathrm{MPa})$ & 713 \\
Ultimate Strength $(\mathrm{MPa})$ & 932 \\
\hline
\end{tabular}

\section{Model Konstitutif Material}

Material baja dimodelkan berdasarkan perilaku density, elastis, dan plastis baja. Modulus elastisitas dan poisson rasio diinputkan pada perilaku plastis baja. Input properti material pada ABAQUS didekati dengan persamaan empiris. Persamaan empiris digunakan untuk menentukan hubungan tegangan-regangan pada tekan beton, tarik beton, dan tarik baja tulangan. Input material beton pada ABAQUS terdiri dari elastic behavior dan Concrete Damaged Plasticity. Elastic behavior berisi input modulus elastisitas dan poisson ratio. Perilaku plastis beton ditentukan dengan Concrete Damaged Plasticity (CDP) pada ABAQUS. Kurva tegangan-regangan beton tekan $\left(f_{c}\right)$ didekati dengan persamaan Razvi dan Saatcioglu[8].

$$
\begin{gathered}
f_{c}=\frac{f^{\prime}{ }_{c c}\left(\frac{\varepsilon_{c}}{\varepsilon_{i}}\right) r}{r-1+\left(\frac{\varepsilon_{c}}{\varepsilon_{i}}\right)^{r}} \\
r=\frac{E_{c}}{E_{c}-E_{\text {sec }}}
\end{gathered}
$$

$f_{c c}^{\prime}$ adalah kekuatan tekan beton terkekang. $\varepsilon_{c}$ dan $\varepsilon_{\mathrm{i}}$ adalah regangan beton dan regangan beton pada saat tegangan puncak. Dimana $\mathrm{E}_{\mathrm{c}}$ dan $\mathrm{E}_{\mathrm{sec}}$ adalah modulus elastisitas dari beton tidak terkekang dan secant modulus elastisitas pada beton terkekang. $\mathrm{r}$ adalah rasio modular. Kurva tegangan-regangan beton tarik $\left(\sigma_{r}\right)$ didekati dengan persamaan Hsu dan Zang[9].

$$
\begin{gathered}
\sigma_{r}=E_{c} \varepsilon_{r} \varepsilon_{r} \leq \varepsilon_{c r} \\
\sigma_{r}=f_{c r}\left(\frac{\varepsilon_{c r}}{\varepsilon_{r}}\right) \varepsilon_{r} \geq \varepsilon_{c r}
\end{gathered}
$$

Dimana $\mathrm{E}_{\mathrm{c}}$ adalah modulus elastisitas beton. $f_{c r}$ adalah tegangan tarik betonyang didapatkan dari persamaan $f_{c r}=$ $3,75 \sqrt{f_{c}^{\prime}} \cdot \varepsilon_{c r}$ adalah rata-rata tegangan tarik beton ketika beton mengalami retak. Kurva tegangan-regangan tulangan tarik $\left(\sigma_{s t}\right)$ didekati dengan persamaan mander[10].

$$
\begin{array}{cc}
\varepsilon_{s t} \leq \varepsilon_{y}: & \sigma_{s t}=E_{s} \varepsilon_{s t} \\
\varepsilon_{y}<\varepsilon_{s t} \leq \varepsilon_{s h}: & \sigma_{s t}=f_{y} \\
& \sigma_{s t}=f_{u}+\left(f_{y}-f_{u}\right)\left(\frac{\varepsilon_{u}-\varepsilon_{s t}}{\varepsilon_{u}-\varepsilon_{s h}}\right)^{P} \\
\varepsilon_{s h}<\varepsilon_{s t} \leq \varepsilon_{u} & \\
: & P=E_{s h}\left(\frac{\varepsilon_{u}-\varepsilon_{s h}}{f_{y}-f_{u}}\right)
\end{array}
$$

Dimana $f_{u}$ dan $f_{y}$ adalah kuat tarik ultimit dan kuat tarik leleh. $\varepsilon_{s h}$ adalah regangan tarik tulangan saat awal hardening. $\varepsilon_{y}$ adalah regangan tegagan tarik tulangan pada saat leleh. $\varepsilon_{s t}$ adalah regangan tarik tulangan. $\mathrm{P}$ adalah rasio strain hardening modulus ke secant modulus diantara koordinat awal dan akhir kurva strain hardening. CDP pada perilaku beton didefinisikan ke dalam plastisitas, perilaku tekan, dan tarik. Perilaku tekan didefinisikan ke dalam hubungan inelastic strain-yield stess dan inelastic straindamage parameter seperti yang disajikan pada Gambar $\mathbf{3}$ dan Gambar 4. Perilaku tarik didefinisikan ke dalam hubungan inelastic strain-yield stess dan inelastic straindamage parameter seperti yang disajikan pada Gambar 5 dan Gambar 6. Regangan plastis didapatkan dari hasil pengurangan regangan beton terhadap regangan elastis. Dari luas trapesium tegangan beton terhadap regangan plastis didapatkan Fracture energy $\left(G_{f}\right)$. Damage parameter beton didapatkan dari pembagian akumulatif Fracture energy $\left(G_{f}\right)$ terhadap total Fracture energy $\left(G_{f}\right)$. Hasil damage parameter untuk beton mutu tinggi pada saat puncak bernilai kecil. Hal ini untuk menghasilkan regangan plastis pada kurva tegangan regangan beton tidak bernilai negatif. 


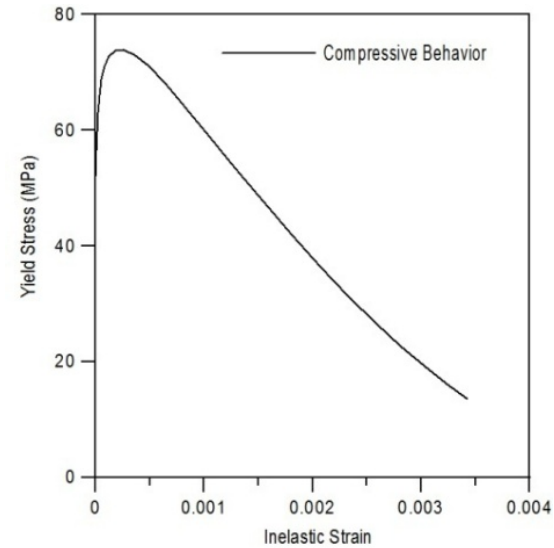

Gambar 3. Kurva Inelastic Strain-Yield Stress Perilaku Tekan $f^{\prime}{ }_{c} 74 \mathrm{MPa}$

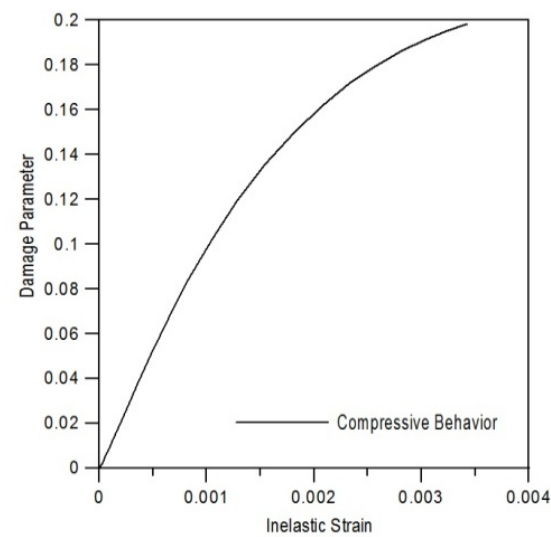

Gambar 4. Kurva Inelastic Strain-Damage Parameter Perilaku Tekan $f^{\prime}{ }_{c} 74 \mathrm{MPa}$

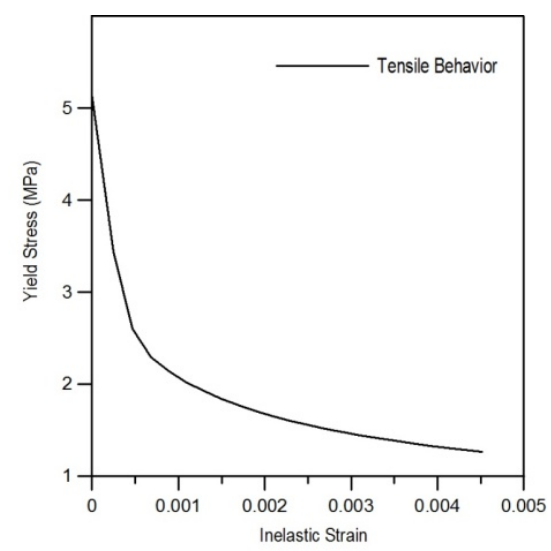

Gambar 5. Kurva Inelastic Strain-Yield Stress Perilaku Tarik $f_{c}^{\prime} 74 \mathrm{MPa}$

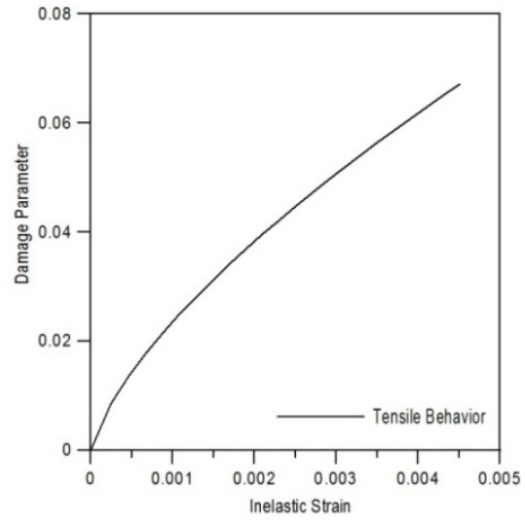

Gambar 6. Kurva Inelastic Strain-Damage Parameter Perilaku Tarik $f_{c}^{\prime} 74 \mathrm{MPa}$

\section{Studi Parameter Material}

Studi input parameter tekan beton dilakukan sebagai verifikasi hasil hubungan tegangan dan regangan beton akibat tekan. Hubungan tegangan dan regangan beton hasil metode elemen hingga (ABAQUS) akan diverifikasi terhadap hasil pendekatan Razvi dan Saatcioglu[8].

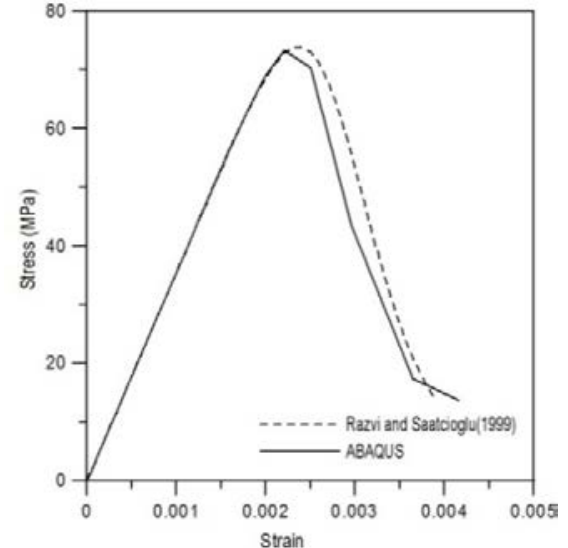

Gambar 7. Kurva Strain-Stress Perilaku Tekan Beton $f_{c}^{\prime} 74$ MPa manual vs ABAQUS

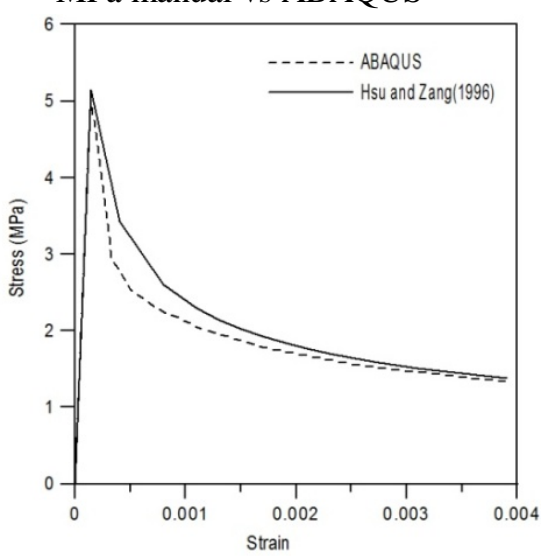

Gambar 8. Kurva Strain-Stress Perilaku Tarik Beton $f_{c}^{\prime} 74$ MPa manual vs ABAQUS 
Hal ini dilakukan untuk membuktikan bahwa input parameter beton pada ABAQUS sudah sesuai dengan hasil tegangan-regangan beton yang diharapkan. Beton dimodelkan sebagai kubus dengan ukuran 100 x $100 \mathrm{~mm}^{2}$ kemudian dibebani titik pada sudut elemen kubus dengan displacement sebesar 5,1 mm pada boundary condition berdasarkan regangan maksimal pada kurva hubungan tegangan-regangan beton. Input material yang diberikan pada ABAQUS adalah berupa hubungan yield stress-inelastic strain dan damage parameter-inelastic strain yang didapatkan dari kurva stress-strain beton.

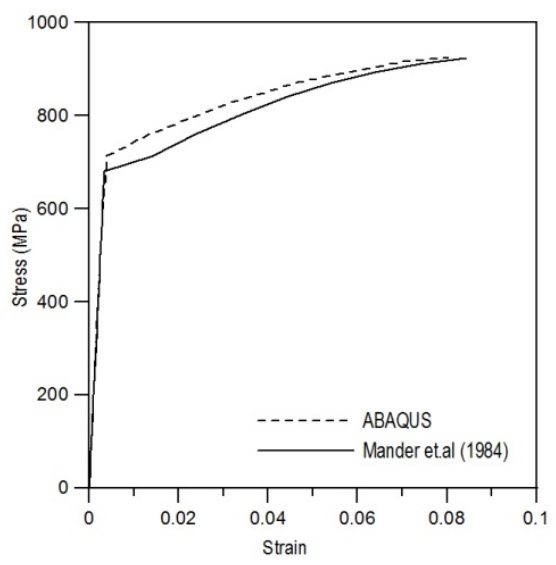

Gambar 9. Kurva Strain-Stress Perilaku Tarik Tulangan SD 685 manual vs ABAQUS

Hasil output tegangan ultimit pada uji axial kubus tekan untuk spesimen $\mathrm{C} 10$ pada pemodelan finite element (ABAQUS) didapatkan sebesar 73,362 MPa yang mempunyai silisih 0,78\% dari tegangan ultimit manual yang ditunjukkan pada Gambar 7. Hasil output tegangan ultimit pada uji axial tarik kubus untuk spesimen C10 pada pemodelan finite element (ABAQUS) didapatkan sebesar 5,0349 MPa yang mempunyai selisih 2,31 \% dari stress ultimit eksperimental yang ditunjukkan pada Gambar 8. Hasil output tegangan ultimit pada uji axial tarik tulangan untuk spesimen C10 pada pemodelan finite element (ABAQUS) didapatkan sebesar $925 \mathrm{MPa}$ pada regangan 0,8 yang mempunyai silisih 0,064 \% dari tegangan ultimit manual yang ditunjukkan pada Gambar 9.

\section{Detail Spesimen}

Spesimen yang akan dimodelkan terdiri dari dua spesimen, yaitu kolom C10 yang diambil dari data penelitian eksperimental Ou et al. [6]. Huruf "C" menotasikan kolom monolit beton mutu tinggi sedangkan angka "10" menotasikan beban aksial $0,1 A_{g} f^{\prime}$. Spesimen dengan beban aksial $0,1 A_{g} f^{\prime}{ }_{c}$ mewakili struktur kolom beton mutu tinggi dengan beban aksial yang rendah (low axial). Spesimen C10 didesain dengan tulangan longitudinal diameter $25 \mathrm{~mm}$ berjumlah 16 buah dan tulangan tranversal diameter $13 \mathrm{~mm}$ dengan jarak spasi antar tulangan $100 \mathrm{~mm}$. Kolom untuk beban aksial $0,1 A_{g} f^{\prime} c$ mempunyai rasio tulangan longitudinal $2,18 \%$ sedangkan rasio tulangan transversal kolom adalah 2,12\%. Ukuran penampang persegi kolom adalah $600 \mathrm{~mm}$ x600 mm dengan tinggi kolom $1800 \mathrm{~mm}$. Kolom dipasang monolit dengan blok beton pada ujung atas dan bawah seperti yang disajikan pada Gambar 10.

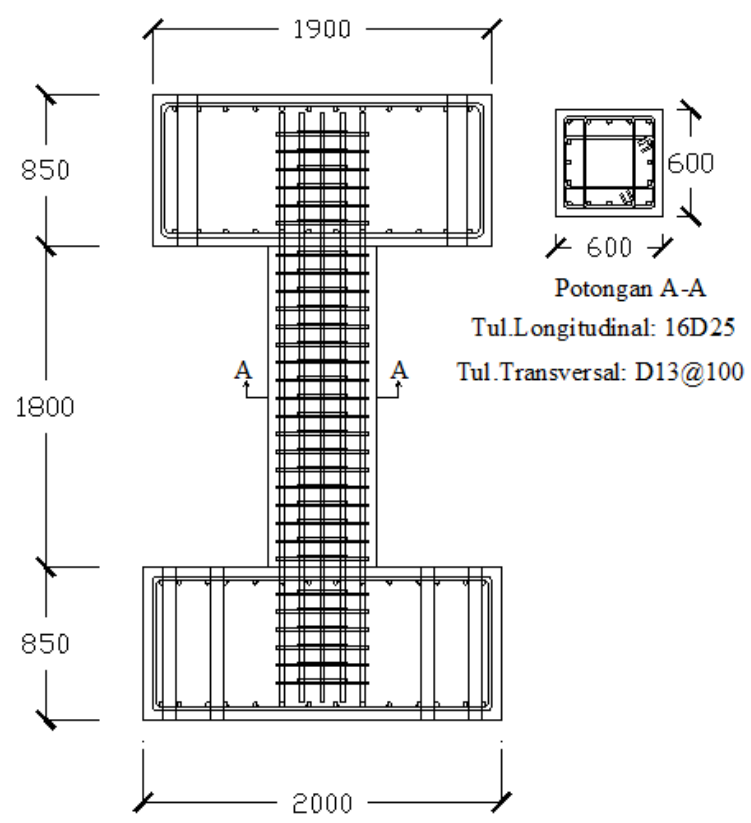

Gambar10. Detail Spesimen Kolom Beton Mutu Tinggi

\section{Pemodelan Numerik}

Pada studi ini digunakan program ABAQUS untuk menganalisa model elemen hingga 3D. Pemodelan part beton kolom menggunakan elemen solid hexahedral yang dinamakan C3D8R sementara tulangan longitudinal dan tulangan transversal menggunakan elemen truss yang dinamakan T3D2 (3D 2 linear displacement nodes) pada ABAQUS. Ukuran meshing pada beton yang digunakan adalah $100 \times 100 \mathrm{~mm}^{2}$.

\section{Skema Pembebanan}

Pembebanan pada model semua spesimen kolom terdiri dari dua beban yaitu beban aksial dan beban lateral displacement. Beban aksial diterapkan pada permukaan blok beton atas seperti yang disajikan pada Gambar 11. Beban tersebut didefinisikan pada ABAQUS sebagai beban pressure sebagai uniform load. Beban aksial diterapkan 
secara konstan. Sementara lateral displacement adalah beban yang berupa dorongan sampai jarak tertentu yang diterapkan bersama beban aksial yang bekerja secara konstan. Perletakan yang digunakan pada pemodelan kolom semua spesimen adalah perletakan roll yang memungkinkan untuk bertranslasi satu arah.

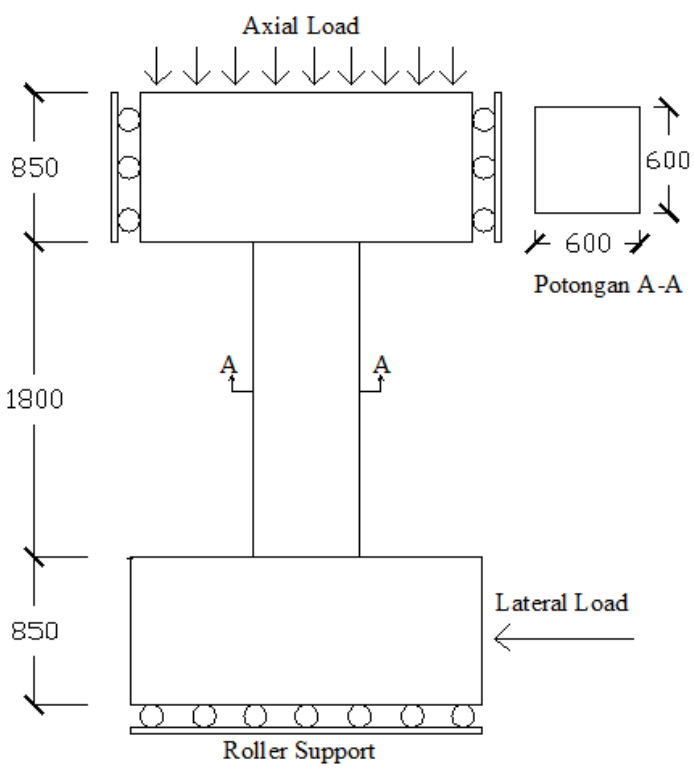

Gambar 11. Skema Perletakan Dan Pembebanan Pada Pemodelan

\section{Hasil Dan Analisa}

Hasil pemodelan kolom beton mutu tinggi adalah kurva force-displacement, tegangan pada tulangan longitudinal, kurvatur dan deformed shape kolom akibat beban aksial konstan dan beban displacement pada pemodelan ABAQUS. Hasil analisa numerik kolom beton mutu tinggi dengan program ABAQUS akan diverifikasi dengan hasil eksperimen pada kolom beton mutu tinggi yang dilakukan oleh Ou et al. [6].

\section{Hubungan Force-Displacement}

Berdasarkan studi input material beton tekan, tarik, dan tulangan tarik hubungan inelastic strain - yield stress dan hubungan inelastic strain - damage parameter diinputkan sebagai material pada pemodelan kolom monolit. Kolom monolit dimodelkan seperti apesimen pada saaat eksperimen dengan blok beton atas, blok beton bawah dan kolom ukuran $600 \mathrm{~mm}$ x 600 mm. Spesimen C10 menggunakan beban aksial 2664 $\mathrm{kN}\left(0,1 A_{g} f_{c}^{\prime}\right)$ dengan beban displacement berdasarkan displacement maksimal hasil eksperimental 55,8 mm. Material yang digunakan adalah beton dengan kuat tekan $74 \mathrm{MPa}$, tulangan longitudinal dengan kuat leleh $713 \mathrm{MPa}$, dan tulangan transversal dengan kuat leleh $886 \mathrm{MPa}$. Pada pemodelan spesimen C10 step yang digunakan terdiri dari 3 step yaitu initial, axial load dan lateral load. Step axial load dan lateral loadmenggunakan maximum number of increments 10000 dengan ukuran increment initial 0,001, minimum $10^{-9}$, dan maksimum 1 . Opsi nlgeom yang mendefinisikan non-linearitas geometrik diaktifkan pada proses simulasi model. Spesimen kolom C10 menggunakan tulangan longitudinal D25 dan tulangan transversal D13 yang didekati dengan elemen TD32 pada ABAQUS. Hasil pemodelan yang ditunjukkan kurva pada Gambar 12 didapatkan dengan viscosity parameter 0,001 dan ukuran mesh $100 \mathrm{~mm}$. Studi mengenai variasi ukuran mesh tidak dilakukan dalam penelitian ini. Elemen solid beton pada model kolom dibagi menjadi beberapa cell sebelum dilakukan meshing pada model. Analisis model kolom menggunakan Hourglass control pada elemen yang dapat meningkatkan akurasi pada model numerik. Perletakan yang digunakan pada pemodelan adalah roll pada tiga sisi seperti pada Gambar 11. Pada saat proses running model kolom monolit proses running berhenti pada displacement 53,3 mm atau drift 2,96 \% dengan pesan " Time increment required is less than the minimum specified" pada ABAQUS. Ini berarti algoritma friksi plastisitas pada model ini kesulitan mencapai konvergen pada increment ke 3345 dari total increment 10000.

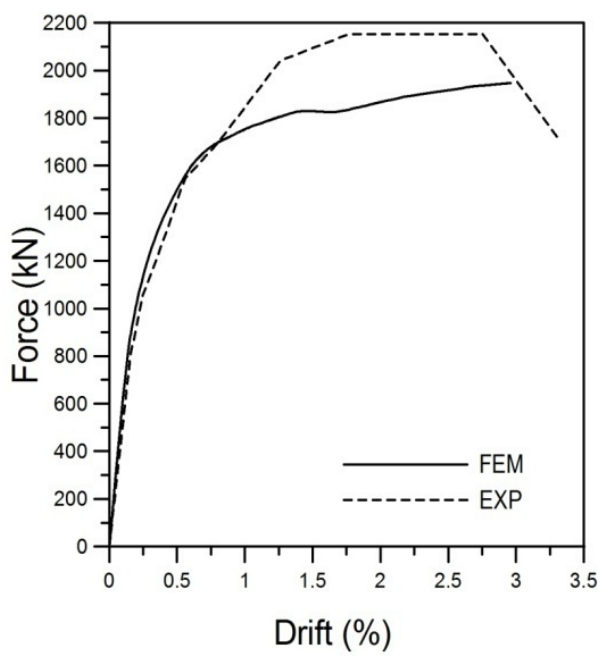

Gambar 12. Kurva Force-Drift Hasil FEA vs Hasil Eksperimen

Hasil output force didapatkan dari jumlah force pada setiap node permukaan yang diberikan beban displacement. Hasil output pemodelan kolom beton monolit untuk spesimen C10 menunjukkan kolom tersebut mencapai puncak penerapan beban sebesar 1946,65 kN pada displacement 53,3 mm 
(drift of 2,96\%). Gambar 12 menunjukkan adanya perbedaan hasil antara hasil output ABAQUS dengan hasil eksperimental pada beban puncak. Beban puncak pada eksperimetal terjadi pada drift $1,77 \%$ dengan penerapan beban 2152 kN. Sementara hasil output pemodelan kolom pada saat displacement 31,6 mm (drift of 1,76 \%) adalah 1834 kN. Perbedaan nilai puncak antara hasil experimental dan numerik terjadi bisa jadi disebabkan pada permodelan kolom ini tidak mempertimbangkan efek kekangan pada beton.

Hasil analisa menunjukkan hasil finite element (ABAQUS) tidak mengalami softening seperti yang terjadi pada eksperimental. Prediksi model kolom monolit menghasilkan respon perilaku softening yang lebih kaku. Perilaku softening pada CDPM ABAQUS juga dibahas dalam investigasi numerik pada kolom concrete-filled-steel-tube (CFST) dibawah beban eksentris yang dilakukanPiscesa et al.[11] menunjukkan bahwa prediksi menggunakan CDPM pada ABAQUS mengalami perilaku softening yang lebih kaku dibandingkan dengan hasil eksperimental. Perilaku softening pada prediksi FEA juga dapat dipengaruhi oleh perbedaan boundary conditions FEA dengan kenyataan pada saat eksperimental. Hal ini juga dapat terjadi karena damage parameter beton yang kecil pada beban puncak. Hal ini juga dapat terjadi karena damage parameter beton yang kecil pada beban puncak. Perbandingan hasil eksperimental dan FEA disajikan pada Tabel 5.

Tabel 5. Perbandingan Hasil Kurva Experiment vs FEA

\begin{tabular}{ccccc}
\hline \multicolumn{2}{c}{ Experiment } & \multicolumn{2}{c}{ FEA } & \multirow{2}{*}{ Ratio } \\
\cline { 1 - 4 } Drift & Applied & Drift & Applied & Ratio \\
Load & Ratio & Load & \\
\hline 0.248 & 1058.925 & 0.249 & 1133.77 & 1.0706803 \\
0.557 & 1543.921 & 0.557 & 1556.55 & 1.0081801 \\
0.800 & 1694.444 & 0.801 & 1697.73 & 1.0019392 \\
\hline
\end{tabular}

\section{Tegangan Pada Tulangan Longitudinal}

Tulangan pada daerah sambungan kolom-blok beton pada kolom spesimen C10 menghasilkan tegangan sebesar 716 MPa seperti yang disajikan pada Gambar 13. Spesimen tersebut sudah mengalami kelelehan pada tulangan dibuktikan dengan tegangan tulangan yang melebihi kuat leleh tulangan longitudinal $713 \mathrm{MPa}$. Tegangan yang terjadi pada tulangan longitudinal dan transversal disajikan pada Gambar 14 menunjukkan tulangan longitudinal dan trasversal mengalami mengalami leleh. Stress maksimal yang terjadi pada tulangan longitudinal adalah sebesar 903.5 MPa pada pada daerah hubungan blok beton-kolom. Kondisi ini menunjukkan bahwa tulangan longitudinal hampir mendekati batas putus tulangan SD685. Tulangan Transversal juga mengalami leleh dengan nilai stress sebesar $900 \mathrm{MPa}$. Posisi leleh tulangan transversal terjadi pada sambungan blok-kolom.

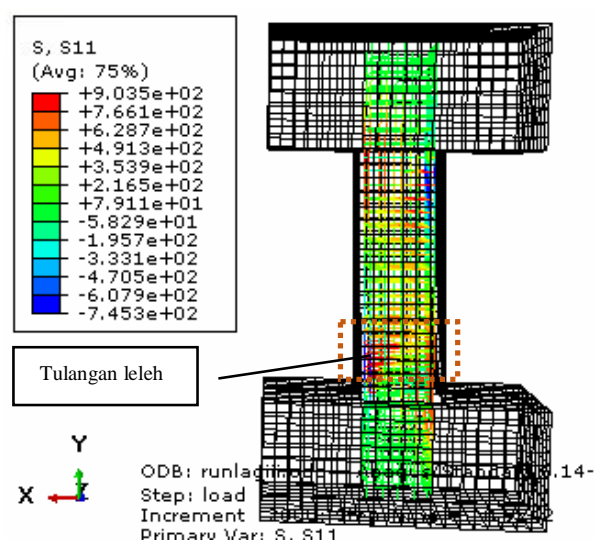

Gambar 13. Tegangan leleh sambungan Hasil FEA (Satuan: MPa)

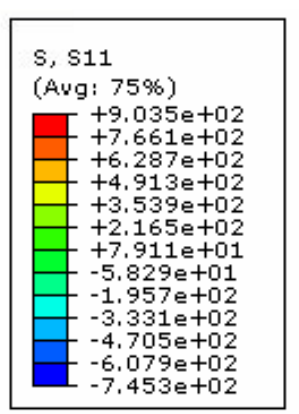

$$
\text { Y }
$$

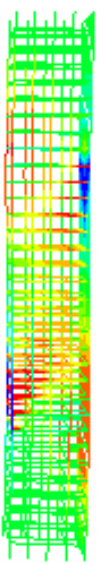

Gambar 14. Tegangan tulangan Hasil FEA (Satuan: MPa)

\section{Deformed Shape}

Pemodelan kolom beton mutu tinggi dengan metode elemen hingga yang dibebani akial dan lateral menimbulkan kerusakan akibat tekan dan tarik seperti ditunjukkan pada Gambar 15 dan Gambar 16. Kerusakan tekan lebih terkonsentrasi pada badan kolom sedangkan kerusakan tarik terkonsentrasi pada sambungan kolom-blok beton.

\section{Simpulan}

Dari hasil permodelan kolom beton mutu tinggi (C10) dengan Abaqus didapat bahwa hasil prediksi force-displacement memberikan korelasi yang baik untuk kekakuan kolom. Adanya perbedaan nilai puncak hasil prediksi ABAQUS dikarenakan pada analisa ini efek kekangan tidak disertakan dalam analisa. Perbedaan perilaku softening antara hasil analisa numerik dan experimental disebabkan prediksi softening dari Abaqus cenderung lebih kaku, dan hal ini sudah pernah dibahas oleh peneliti yang lain. 
Dari kurva force-displacement korelasi antara hasil eksperimental kolom beton mutu tinggi C10 dan hasil output ABAQUS kolom beton mutu tinggi C10 menunjukkan prediksi FEA mempunyai korelasi yang baik sampai pada fase non linier (setelah elastis) pada drift $0.248 \%, 0.557 \%$, dan $0.8 \%$.

Berdasarkan hasil analisa FEA pada kolom beton bertulang mutu tinggi perlu adanya studi lebih lanjut mengenai pengaruh parameter viskositas dan sudut dilatasi CDP pada pemodelan kolom beton pracetak mutu tinggi menggunakan program FEA ABAQUS. Perlu dilakukan studi lebih lanjut mengenai efek kekakangan pada pemodelan kolom dengan beban lateral menggunakan program FEA ABAQUS.

\section{Daftar Pustaka}

[1] H. Aoyama, Design of Modern Highrise Reinforced Concrete Structures, vol. Vol. 3. 2001.

[2] TCI, “Taiwan Concrete Institute 鋼筋混凝土用鋼筋 Steel bars for Concrete Reinforcement,” 2013.

[3] Y.-C. Ou and D. P. Kurniawan, "Shear behavior of reinforced concrete columns with high-strength steel and concrete under low axial load," Am. Concr. Institute, ACI Spec. Publ., no. 293 SP, pp. 1-12, 2012.

[4] Y. C. Ou and D. P. Kurniawan, "Effect of axial compression on shear behavior of high-strength reinforced concrete columns," ACI Struct. J., vol. 112, no. 2, 2015.

[5] S. Hwang, G. Hwang, F. Chang, and Y. Chen, "Design of Seismic Confinement of Reinforced Concrete Columns Using High Strength Materials," Am. Concr. Institute, Farmingt. Hills, Mich, vol. SP293, pp. 21-34, 2013.

[6] Y. C. Ou, H. Alrasyid, Z. B. Haber, and H. J. Lee, "Cyclic behavior of precast high-strength reinforced concrete columns," ACI Struct. J., vol. 112, no. 6, pp. 839-850, 2015.

[7] W. C. Liao, W. Perceka, and M. Wang, "Experimental study of cyclic behavior of high-strength reinforced concrete columns with different transverse reinforcement detailing configurations," Eng. Struct., vol. 153, pp. 290-301, 2017.

[8] S. Razvi and M. Saatcioglu, "CONFINEMENT MODEL FOR HIGH-STRENGTH CONCRETE,” J. Struct. Eng., pp. 281-289, 1999.

[9] T. T. C. Hsu and L.-X. Zhang, "Tension Stiffening in Reinforced Concrete Membrane Elements,” ACI Struct. J., vol. 93, no. 1, pp. 108-115, 1996.

[10] J. B. Mander, "Seismic Design Of Bridge Piers," University of Canterbury, 1983.

[11] B. Piscesa, M. Attard, A. Samani, and P. Suprobo, "Numerical Investigation on The Behavior of Concrete-Filled-Steel-Tube Column under Eccentric Loading,” Third Int. Conf. Civ. Eng. Res., no. August 1st-2nd 2017, pp. 1-6, 2017.
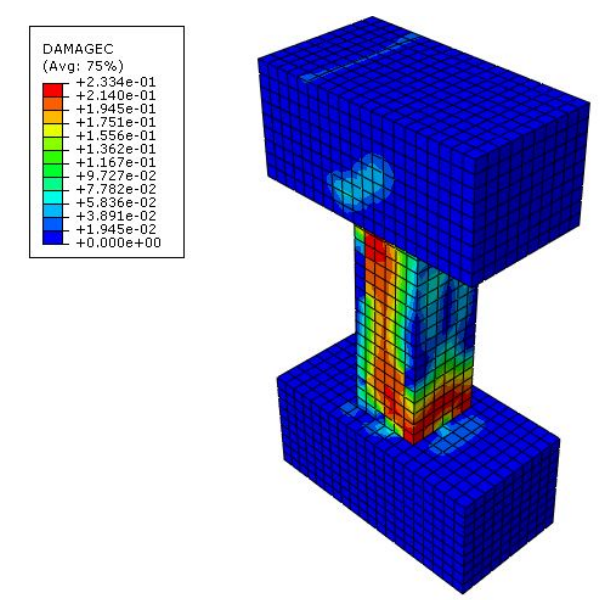

Gambar 15. Damage Compression Kolom hasil output FEA ABAQUS
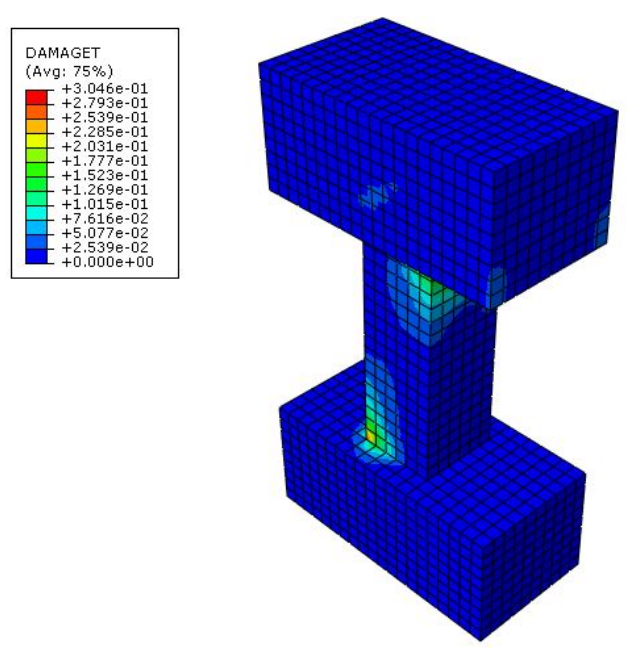

Gambar 16. Damage Tension Kolom hasil output FEA ABAQUS 